\title{
The Utah Botanical Gardens: An Educational Resource for the University and the Community
}

Shawn O Isen, ${ }^{1}$ D ebbie Amundsen, ${ }^{2}$ Bill Varga, ${ }^{2}$ D onna M inch, ${ }^{3}$ and D ave Anderson ${ }^{4}$

AdDitional INDEX WORDs. extension, ornamental trials, display gardens, off-campus credit classes, certified nursery professional

Summary. U niversity students have been involved with the $U$ tah Botanical G ardens (U BG) since their inception in 1954 as part of the $U$ tah State $U$ niversity (U SU ) U tah Agricultural Experiment Station (U AE S). Students and professors travel from U SU to visit U BG, conduct class tours, and participate in research projects. Students also work at U BG as summer interns, and in 1986, U SU began offering off-campus horticulture classes for credit at U BG. T oday, 20 different classes are taught at U BG or nearby sites. These classes are part of the U SU Applied $O$ rnamental $\mathrm{H}$ orticulture degree program and can also be used to qualify as a $\mathrm{C}$ ertified $N$ ursery Professional by the $U$ tah $N$ ursery and L andscape Association.

$\mathrm{T}$

he $U$ tah Botanical Gardens (U BG) is a partnership between the U tah Agricultural Experiment Station (U AES), D epartment of Plants, Soils, and Biometeorology (PSB), and U tah State U niversity (U SU ) Extension. The U BG is located in Farmington, 60 miles $(96 \mathrm{~km})$ south of the U SU campus in Logan. The U tah Board of Regents has designated USU to be the provider of horticulture degree programs in the state, and in 1986, the PSB D epartment began offering an off-campus credit horticulture program at the U BG. This primarily brought classes to the Wasatch Front (major metropolitan area surrounding Salt Lake C ity) where the majority of the horticulture students and green industry employers are located; because these students were employed during the day, classes were taught in the evening. The off-campus program was an extension of the Applied O rnamental $\mathrm{H}$ orticulture 2-year degree that has been offered on campus at U SU since 1977.

\footnotetext{
U tah State U niversity, Logan, UT 84322-4900.

This project was supported by the $U$ tah Agricultural Experiment Station, journal article no. 7048. The cost of publishing this paper was defrayed in part by the payment of page charges. U nder postal regulation, this paper thereforemust behereby marked adverti sement solely to indicate this fact.

${ }^{1}$ D avis County Extension Director, U tah State U niversity, P.O. Box 618, Farmington, U T 84025.

${ }^{2}$ Assistant D irector and D irector, U tah Botanical Gardens, D epartment of Plants, Soils, and Biometeorology, U tah State U niversity, Logan, U T 84322-4820.

${ }^{3} \mathrm{O}$ ff Campus C oordinator, Applied O rnamental H orticulture Program, 567 East 500 S., Farmington, U T 84025

${ }^{4}$ Project D irector, U tah Botanical C enter, U tah State U niversity, Logan, U T 84322-4055.
} 


\section{Garden history}

O rnamental plant trials were initiated in 1926 at the Farmington Field Station of the $\mathrm{U}$ tah Agricultural Experiment Station where researchers evaluated trees and shrubs. In 1954, flower variety trials were added, and the station became known as the Farmington Display Gardens. In the early 1970 s, plant materials were reconfigured from row plots to landscaped beds and theme gardens to achieve a more aesthetically pleasing effect and greater accessibility.

In 1980, an extension gardening office was opened to provide improved educational programs and services for the public, including the first $M$ aster $G$ ardener program in the state. Since 1980, the U BG has been used for hundreds of $M$ aster $G$ ardener classes, public classes, pruning demonstrations, and greenhouse classes. $\mathrm{H}$ orticulture classes from the USU campus visit the UBG for field trips, laboratories, and demonstrations. In 1984, the site officially received its current name of the U SU / U BG from the U tah L egislature. In 1986, the U BG became directly involved in horticulturetraining by offering $U \mathrm{SU}$ credit classes on site.

\section{Credit classes offered}

Surveysin 1979 and 1986 (Long, 1987) show that ornamental horticulture employers prefer employees with education and experience. In U tah, employment in the ornamental horticulture industry increased from 7,800 people in 1979 to 11,740 people in 1986. A 1992 survey (Snyder and Wilde, 1992) indicated that the $U$ tah green industry employed more than 15,400 people with a total payroll of $\$ 350$ million. With a growing green industry, there was an increased demand for trained, experienced horticulture students.

From 1986 to 1989, off-campus, credit-based horticulture classes were taught at the UBG in Farmington by campus faculty, who also coordinated the program. The first courses offered wereSustainableL andscapes, Annual and Perennial Plants, and $\mathrm{H}$ orticulture Science.

Beginning in 1989, classes for credit were expanded to the Salt Lake C ounty extension office. Later, with increasing student numbers, classes were taught at the $U$ niversity of $U$ tah's ( $U$ of $U$ ) Red Butte Garden and Arboretum, Salt L ake Community College (SLCC), Weber State U niversity (WSU), U tah Valley State College (UVSC), Provo $\mathrm{H}$ igh School and Orem High School. The classes are U SU courses, although they are taught at several locations, since enrollment and student registration are handled by USU Extension Continuing Education. As more classes were offered, additional instructors were selected from main campus faculty, extension horticulture agents, high school vocational instructors, and adjunct faculty from the green industry.

In 1994, 82 students attended one or more classes at the U BG or nearby locations. Classes taught at the $U$ BG remain some of the most popular due to the plant collections and greenhouses, nearby research plots, and easy access and parking. In 1995, an offcampus program coordinator was placed at the U BG in Farmington. The coordinator is assigned to the PSB Department and develops class schedules, advertises classes, and assists students with career plans. $\mathrm{H}$ aving a local coordinator helped increase student enrollment. By 1997, 174 students were taking 24 different classes along the Wasatch Front. In 1998, U SU switched from a quarter to a semester system, resulting in the combining and renaming of several classes. Currently, there are 19 courses offered with 17 different instructors(Table1). Themajority of students take only U SU horticulture classes in the evening. Some students take electiveand general education classes at theU of U, SLCC, UVSC, or WSU during the day and U SU horticulture classes at night. Information sheets are prepared that list USU equivalent courses at other institutions for students seeking a B.S. degree from U SU .

T able 1. U tah State U niversity (U SU) credit classes taught at the U tah B otanical G ardens (U B G ) and nearby sites. All classes are taught at the U B G. Other sites are used depending on registration and facilities needed. C lasses are listed with course number (PISc = Plant Science), semester credit hours, title, and semester taught ( $\mathbf{F a}=$ Fall, Sp $=$ Spring, Su $=$ Summer $)$.

\begin{tabular}{|c|c|c|}
\hline Course no. & C redit hours & C ourse name \\
\hline PISc 2600 & 1.5 & Annual and Perennial Plants (Su) \\
\hline PISc 3600 & 2 & Arboriculture (Sp) \\
\hline PISc 3010 & 2 & Basic Flower Arrangement ( $\mathrm{Fa}$ ) \\
\hline PISc 4500 & 4 & Fruit Production (Sp) \\
\hline Soils 3000 & 4 & Fund Soil Science (Fa, Sp) \\
\hline PISc 3050 & 4 & Greenhouse M anagement/ Crop Production (Sp) \\
\hline PISc 3200 & 3 & H orticultural Science ( $\mathrm{Fa}, \mathrm{Sp})$ \\
\hline PISc 2650 & 1 & I dentification of Plants (Fa) \\
\hline PISc 2610 & 1.5 & Indoor Plants (Sp) \\
\hline PISc 2250 & $1-4$ & O ccupation Experience ( $\mathrm{Fa}, \mathrm{Sp}, \mathrm{Su})$ \\
\hline PISc 2200 & 3 & Pest $M$ anagement (Sp) \\
\hline PISc 3700 & 3 & Plant Propagation (Sp) \\
\hline PSB 1050 & 1 & Plant, Soils, Biometeorology O rientation (Fa) \\
\hline PISc 3300 & 3 & Residential L andscapes (Sp) \\
\hline PISc 2900 & $1-4$ & Special Problems (Fa, Sp, Su) \\
\hline PISc 3400 & 3 & Sustainable L andscapes ( $\mathrm{Fa}$ ) \\
\hline PISc 3800 & 3 & Turfgrass $\mathrm{M}$ gmt ( $\mathrm{Fa})$ \\
\hline PISc 4400 & 3 & Vegetable Production (Fa) \\
\hline PISc 2620 & 3 & Woody Plant $\mathrm{M}$ aterial $(\mathrm{Fa})$ \\
\hline
\end{tabular}


T able 2. M ajor components of the $U$ tah B otanical $G$ arden used in course instruction.

\begin{tabular}{|c|c|}
\hline Component & Description \\
\hline General gardens & $\begin{array}{l}\text { Annual flower display gardens, including All-American Selection winners } \\
\text { Theme gardens, including perennials, dry river bed, shade plants and herbs } \\
\mathrm{N} \text { ative plant garden } \\
\text { Vegetable and small fruit demonstration garden } \\
\text { Rose (Rosaceae) garden with hybrid tea, old-fashion, English and heritage selections }\end{array}$ \\
\hline Specific collections & $\begin{array}{l}\text { D aylily (H emerocallis L.) collection of } 185 \text { selections } \\
\text { Peony (Paeonia L.) collection of } 20 \text { selections } \\
\text { I ris(I risL.) collection of over } 400 \text { selections, including all D ykes M edal winners and aU tah I ris H ybridizer Garden } \\
\text { Shrub and dwarf conifer collection } \\
\text { M ature shade tree collection planted in } 1963\end{array}$ \\
\hline
\end{tabular}

The number of classes taught and students enrolled is unique for an offcampus horticulture program in the intermountain west of the U.S.

\section{Course instruction at UBG}

Course instruction at the UBG includes lectures, greenhouse work, and tours of the plant collections on the grounds (Table 2). The 7-acre (2.8-ha) site has mature plantings of trees, shrubs, ground covers, and vines that are adapted to the $U$ tah environment. Plants are labeled with their common name, botanical name, and year planted. Students can discuss different plant materials in the classroom and then observe plants in the U BG just outside the classroom (Fig. 1).

The U BG plant collection isstudied extensively in classes such as Arboriculture, Woody Plant $M$ aterials, and Annual and Perennial Plants. A favorite teaching technique in these classes is to cover up the plant identification tags with brown paper bags and then quiz students on the plant's common name, botanical name and hardiness zone (Fig. 2). In Arboriculture, students prune plants at the U BG and nearby public schools. The mature shade trees are studied extensively in R esidential $L$ andscapesto evaluatesize, spacing, and landscape value.

In T urfgrass $M$ anagement and in Pest $M$ anagement, students learn to use a sprayer; in Sustainable Landscapes, students study a small section of the UBG in detail and develop a comprehensive maintenance schedule for that section. Students also evaluate water use, irrigation needs, and sprinkler systemsin Sustainable L andscapes. In Annual and Perennial Plants, the class designs and installs an annual flower garden.

InPlant Propagation, theclasstakes woody and herbaceous cuttings from the U BG collection for rooting observation in the greenhouse. The Flower Arranging class removes cut flowers to practice arrangements. In Fundamentals of Soil Science, students learn principles of soil sampling and dig soil profile pits to study soil types.

In the greenhouse-based classes, studentswork in the U BG greenhouses to produceplantsfor the U BG grounds. $O$ ne greenhouse section is reserved for astudy collection of house plantsfor the Indoor Plants class. Local greenhouse businesses also cooperate by providing cutroses, potted mums, transplant plugs, and other plant materialsthat are used in classinstructionsand demonstrationsat the U BG.
A nearby U BG partner also used in teaching classes for credit is the U AES Kaysville Research Farm. This 62-acre (25-ha) farm is located $2 \mathrm{mi}(3.2 \mathrm{~km})$ from the $U B G$ and is used by campusbased research faculty for studies on tree fruits, vegetables, ornamentals, and rangeland grasses. $M$ any research leaders al so teach classes at the U BG, working on their research plots during the day and then teaching an evening class. These research plots are frequently utilized for selected teaching activities. C lassesnormally visit theK aysvilleFarm for the first part of the weekday class, or on Saturday, as part of a lab exercise.

\section{Fig. 1. Students in a class at the $U$ tah B otanical $\mathbf{G}$ ardens learn about different plant materials and can then observe plants in the gardens just outside the classroom.}

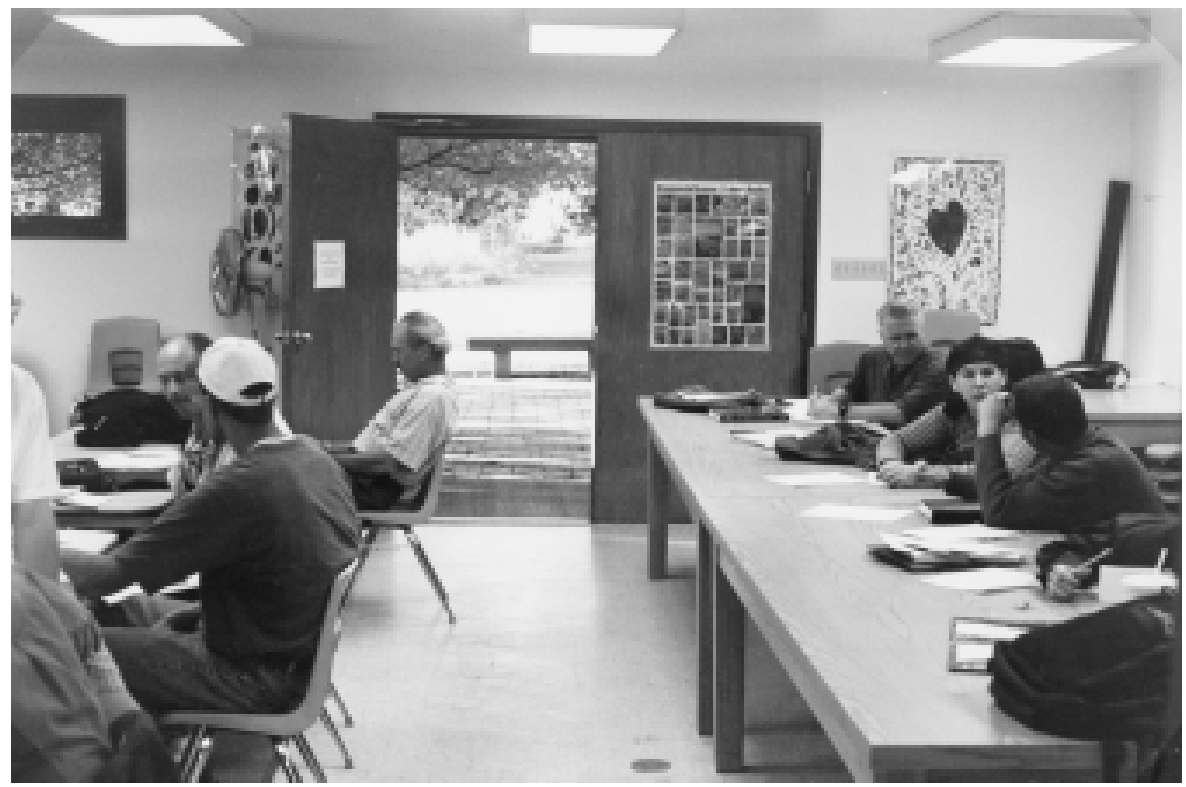




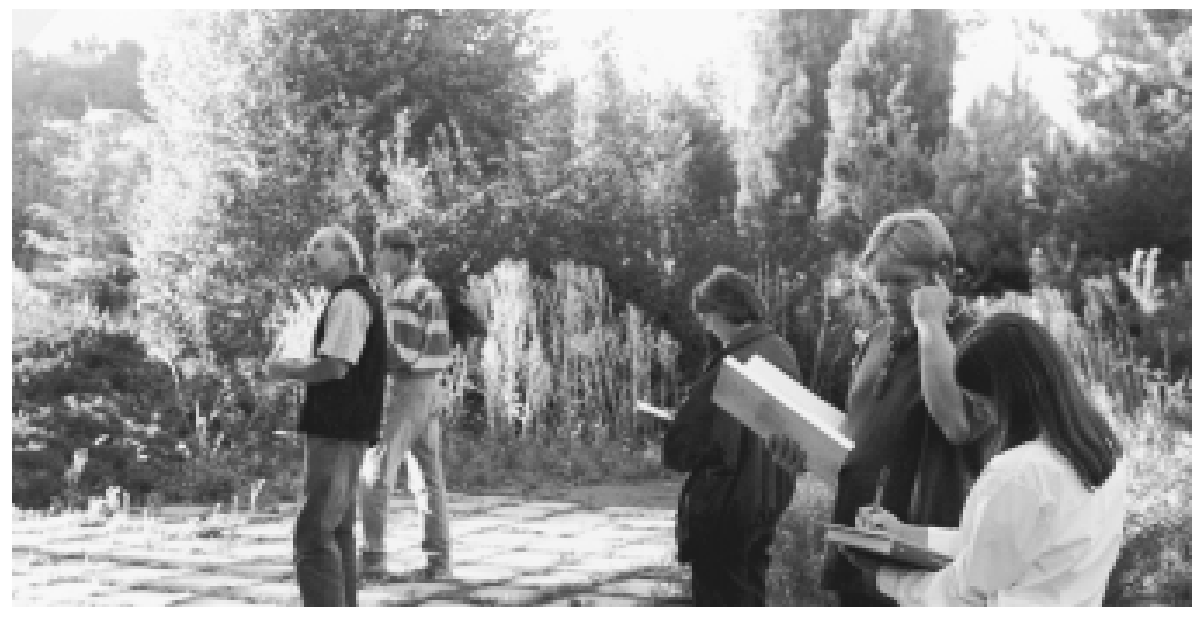

Fig. 2. Students in a Woody Plant $M$ aterials class take a quiz which asks for common name, scientific name, and hardiness zone of landscape plants.

Students in the Fruit Production class prune a selected block of trees after a demonstration by the class instructor, grafting and budding are demonstrated in the orchard, and insect monitoring traps can be seen in the I ntegrated Pest $M$ anagement Research $O$ rchard. Proper pesticide use and storage are demonstrated for students using a modern pesticidestoragebuilding and rinsepad.

\section{Partnership with Utah green industry}

The $U$ tah N ursery and L andscape Association (U NLA) has been an important partner in promoting horticulture classes for credit at U BG (Linde, 1992). Each quarter, a list of upcoming classesis sent to nurseries, greenhouses, golf courses, public works departments and previous students. The list is also published in the U NLA newsletter and a compilation of job openings from U N LA businesses is included in a class schedule that issent quarterly to current students. The U N LA offers two college scholarships each year for horticulture students, with many having gone to students in the off-campus program. Three U SU horticulture class instructors serve as ex-officio members of the UNLA Board of Directors, enabling them to monitor needs for new or expanded class offerings.

The U N LA helps sponsor an annual $\mathrm{U}$ tah $\mathrm{G}$ reen Industry Conference and Trade Show. Students enrolled in USU classes are able to attend for a reduced rateand can earn Special Problems credit by attending the conference and writing a summary report. This elective credit helps fulfill degree requirement hours.

\section{Degree and certification programs}

StudentswhotakeclassesattheU BG qualify for U SU degrees and special certification programs. For example, many studentsworkingolfcoursegroundsmaintenance. By completing an Associate D e gree, these students can obtain the Certified Golf CourseSuperintendent (CGCS) designation with only 5 yearsof experience instead of 8 years. A CGCS designation enablesstudentsto advance in thisprofession and gain employment at more prestigious golf courses.

For many years, the U BG has been an educational resource for the certification exams of the $U$ tah Certified N ursery Professional program in conjunction with the U NLA. With the development of a broad range of credit-based classes, the certification program wasmo dified to providecertification upon completion of these classes: PISc 2200-Pest M anagement, PISc 3200-H orticultural Science, PISC 3300-Residential L andscapes, and PISc 2620-Woody Plant M aterials. In 1997, ten of 24 new nursery professionals completed certification by taking credit-based classes (J ones, 1998).

\section{The future}

The 72-year history of the U BG in Farmington will soon draw to a close. Because of expansion of the adjacent state highway, the gardens will be relocated and become part of thenew $U$ tah Botanical C enter (U BC) on 94 acres (38 ha) adjacent to the existing UAES Kaysville Research Farm. This move will consolidate horticulture research and education programs. O ffice space, classrooms, research plots, extension staff, and teaching faculty will be at one location. At the new Kaysville location, work is under way on utilities, roads, and relocation of plant material from the current Farmington site. D evelopment of a woody plant material teaching garden is one of the first projects for the new facility, grouping treesand shrubs by plant family. Another project is establishment of a Certified N ursery Professional testing facility in cooperation with the UNLA.

In planning the $B C$, surveyswere made of PSB faculty, county extension agents, M aster Gardeners, the $\mathrm{U}$ tah nursery industry, and local citizens. The feedback from over 580 surveys lead to a refinement of the $U B C$ mission and the development of a master plan.

The U BC will emphasize sustainable urban landscapes, resource conservation, and environmental sensitivity, addressing issues of wetland restoration and water quality en hancement. O ff-campus, credit-based horticulture classes will continue and will be expanded with additional classroom space, more greenhouses, and satellite television programs.

Theoff-campuscredit-based classes have becomeinvaluablefor horticulture students who want to work near their homes and attend university classes at night. I mproved teaching facilities and an expanded plant material collection at the UBC will enable PSB and USU extension to meet the growing demand for horticulture education.

\section{Literature cited}

Jones, D. 1998. U tah certified nursery professionals, 1997. T runklineN wslt. U tah N ursery Landscape Assn. 14(1):5.

Linde, S. 1992. G reen industry employees need better training. T runklineN wslt. $U$ tah N ursery Landscape Assn. 8 (3):5, 11.

Long, G.A. 1987. Employment opportunities in ornamental horticulture and agricultural mechanization. U tah Sci. 48(3):124

Snyder, D. and R. Wilde. 1992. The economic impact of U tah's green industry. Res. Rpt. U tah Agr. Expt. Sta. 144. 